\title{
Gammarid amphipods (Crustacea) in Norway, with a key to the species
}

\author{
Wim Vader' and Anne Helene S. Tandberg ${ }^{2}$
}

\begin{abstract}
Vader W and Tandberg AHS. 2019. Gammarid amphipods (Crustacea) in Norway, with a key to the species. Fauna norvegica 39: 12-25.

Thirteen species in the amphipod family Gammaridae have been reported from Norway. This paper gives a survey of the distribution and habitat of all 13 species of the family Gammaridae occurring or expected to occur in Norwegian waters: both marine, brackish and fresh, including Svalbard, in addition to four species found in close neighbouring waters. It also provides a short history of the study of Gammaridae in Norway, as well as an illustrated identification key to all species in the area.
\end{abstract}

doi: 10.5324/fn.v39i0.2873. Received: 2018-11-28. Accepted: 2019-02-10. Published online: 2019-02-28. ISSN: 1891-5396 (electronic).

Keywords: Gammarus, Marinogammarus, Amphipoda, identification key, habitat

1. Tromsø Museum - Universitetsmuseet, Universitetet i Tromsø, NO-9037 Tromsø, Norway.

2. Universitetsmuseet i Bergen, avd for Naturhistorie, PO Box 7800, NO-5020 Bergen, Norway.

Corresponding author: Anne Helene S. Tandberg

E-mail: anne.helene.tandberg@uib.no

\section{INTRODUCTION}

The many similar-looking amphipod species in the family Gammaridae, collectively called 'marflo' in Norwegian, are both widespread and numerous many places, in fresh water, brackish water, and on the sea shore. They are an important part of the various ecosystems, they are good indicators of water quality, and they are also often used in toxicology studies. To identify them to species, however, is not always easy. The usual identification method for amphipods we use in Norway, i.e. the combination of the always excellent illustrations in the old monograph by G.O.Sars (1890-95) with the keys and distribution data in the various papers by Stephensen (1928, 1929, 1935-42), fails dismally in this case: Sars (op. cit.) described only five species of Gammarus, three in sea water $(G$. locusta, G. campylops, G. marinus), one in brackish biotopes (G. duebeni) and one in fresh water (G. pulex). Now, however, we know 13 species in Norway (without, by the way, either $G$. campylops or G. pulex).

The aim of this paper is 1 . To give a short historical overview of the study of Gammarus species s.l. in Norway, 2. To provide an illustrated identification key to the Norwegian Gammaridae species, including a few species that have not yet been found here, but may occur, 3 . To give references to good descriptions and illustrations of all species, and 4 . To give a short review of the distribution and habitat of every species in Norway.

There are some further freshwater amphipods in Norway, that traditionally have been reckoned in the Gammaridae s.l. These are the so-called 'glacial relicts' Gammaracanthus lacustris (Sars, 1867) and Pallasea quadrispinosa (Sars, 1867), that occur in some deep lakes in SE Norway; Pallasea has recently also been discovered on Jæren (Spikkeland et al. 2012). A marine Gammaracanthus species also occurs in Arctic waters. These are now considered to belong to the families Gammaracanthidae and Pallaseidae, and are not dealt with here. A further, non-indigenous freshwater amphipod has very recently been found on Jæren, i.e. Crangonyx pseudogracilis Bousfield, 1958 (Spikkeland et al. 2016); this species belongs in the family Crangonyctidae, and is also excluded.

In recent years, many places in Europe, in both fresh and brackish waters, have had an influx of Ponto-Caspian species, especially in rivers and in the inner parts of the Baltic Sea. One of these is the ill-famous 'killer amphipod' Dikerogammarus villosus (Sowinsky, 1894). None of these species have hitherto been recorded in Norwegian waters and we have not included them in this paper, with the exception of the American immigrant Gammarus tigrinus Sexton, 1939. 


\section{History}

The development of gammarid classification in northern Europe in the last 100-150 years seems to have happened in definite stages. In the first stage a number of species was described: Gammarus kröyeri Rathke, 1843, G. poecilurus Rathke, 1843, G. duebeni Liljeborg, 1852, G. mutatus Liljeborg, 1855, G. batei Boeck, 1861 and G. lacustris Sars, 1863. In most cases there was no type material conserved and the descriptions are so vague and incomplete that it is now often practically impossible to identify these species. In the next stage practically all these species were again viewed as junior synonyms of the three classic Gammarus species of the area: Gammarus locusta, G. marinus and G. pulex. Characteristic for this stage is e.g. that Liljeborg already in 1855 reduced his own $G$. duebeni to a synonym of G. locusta, while Sars in 1892 no longer saw his own G. lacustris as different from G. pulex; both, as we now know, incorrect decisions.

The third stage started with Sexton who, starting around 1910 , over many years carried out a large number of rearing and crossing experiments with various Gammarus species in the Plymouth laboratory in England (see e.g. Sexton 1923, Sexton \& Clark 1936). She found that the species were not at all so variable as everybody thought at the time: even when reared under quite different regimes, specimens at the same stage of development remained morphologically extremely similar. Sexton also described a few new species from brackish water, i.e. Gammarus zaddachi in 1912. She was clearly far ahead of her time, however, and it took more than 25 years for the leading European specialists (Chevreux, Schellenberg, Stephensen) to accept $G$. zaddachi as a valid species.

In the 1930's there was a change again, and new species were described regularly, usually without comparing them with the names from the first stage. In 1930 Gurjanova recognized Birula's Gammarus wilkitzkii as 'a good species'. In 1931 followed Gammarus setosus Dementieva and Rivulogammarus scandinavicus S. Karaman (= G. lacustris), in 1938 G. finmarchicus Dahl (in the same year also described from USA as G. greenfieldi Shoemaker), G. obtusatus Dahl and G. stoerensis Reid, in 1939 G. tigrinus Sexton, and in 1940 Marinogammarus pirloti Sexton \& Spooner. In 1942 Sexton divided her Gammarus zaddachi into a 'freshwater' and a 'saline' form, in 1947 called G. z. zaddachi and G. z. salinus by Spooner. That same year Segerstråle (1947) described a third, more northern form as G. z. oceanicus, and all three forms were upgraded to species level by Kinne (1954). This almost completed the picture for NW Europe, except for the splitting of the Gammarus locusta group by Stock $(1966,1967)$, who i. a. showed that Sars's G. campylops, until then looked at as a synonym of $G$. locusta, in reality represented an independent species, which he named G. inaequicauda (Stock \& Kant, 1966).

As we see, in this period also a few new genus names appear, besides the original Gammarus: Rivulogammarus S. Karaman, 1931 for freshwater species, Marinogammarus
Sexton \& Spooner, 1940 for the species of the stony littoral, and Lagunogammarus Sket, 1971 for the greater G. zaddachi group. Rivulogammarus is not an available name, having the same type species as Gammarus (Stock 1969a), while Lagunogammarus, although taken in use in her monograph by Tzvetkova (1975) is also no longer in use (Hou \& Sket 2016). As shown below, the situation for Marinogammarus is more complicated.

In this period several different classification and systematics models were taken in use in taxonomy: phenetics, cladistics, molecular classifications, and in our opinion a final classification of European gammarids has not yet been obtained. Stock (1968, 1969b, Pinkster \& Stock 1970) worked on Marinogammarus (which he replaced by the older name Chaetogammarus, coined for a Black Sea species); he removed M. obtusatus to the Baikal genus Eulimnogammarus (a move no longer followed by anyone), and $M$. finmarchicus back to Gammarus s. str., close to G. duebenii.

The latest revision is that by Hou and Sket (2016), and even though also that one has already drawn criticism and has not yet been followed by WoRMS (Horton et al. 2018), it is used here. They restored the genus Marinogammarus (still called Echinogammarus in WoRMS), but in a most interesting development these authors also declared M. stoerensis to be the probable sister group of all remaining gammarids and erected the genus Relictogammarus for this species (Hou \& Sket 2016); also this species is accepted as Echinogammarus in WoRMS.

The present paper deals with the following 17 species, of which $4\left(^{*}\right)$ have not yet been recorded from Norwegian waters, but may conceivably occur there:

\section{* Gammarus crinicornis Stock, 1966}

G. duebenii Liljeborg, 1852

G. inaequicauda Stock, 1966

G. lacustris Sars, 1863

G. locusta (Linnaeus, 1758)

G. oceanicus Segerstråle, 1947

* G. pulex (Linnaeus, 1758)

G. salinus Spooner, 1947

G. setosus Dementieva, 1931

* G. tigrinus Sexton, 1939

* G. wilkitzkii Birula, 1897

G. zaddachi Sexton, 1912

Marinogammarus finmarchicus (Dahl, 1938)

M. marinus (Leach, 1815)

M. obtusatus (Dahl, 1938)

M. pirloti Sexton \& Spooner, 1940

Relictogammarus stoerensis (Reid, 1938)

\section{Identification key}

In the construction of this key we have, as always in such cases, based ourselves for a large part on earlier work by Sexton \& Spooner (1940), Reid (1944), Kinne (1954), Hynes et al. (1960), Stock (1966, 1967), Bousfield (1969) and Lincoln (1979), but in a few cases we have chosen new criteria. The key will work for 
adult and subadult specimens, but is not reliable for juveniles and small immatures. For illustrations to the key, see figs 1 and 2. All illustrations are based on drawings originally presented in Sars (1890-95), Sexton \& Spooner (1940), Sexton (1942), Stephensen (1949), Barnard (1959), Økland (1969), Pinkster (1970), Bousfield (1973) and Lincoln (1979).

\section{Key to the Gammarus/Marinogammarus/Relictogammarus in Scandinavian waters (Adult specimens)}

1. a) U3 outer ramus with only 1 article. (Inner ramus $30-40 \%$ of outer ramus length. P7 basis posterodistally with only setae.)

Marinogammarus finmarchicus (Dahl, 1938)

b) U3 outer ramus with 2 articles 2

2. a) U3 inner ramus more than half length of outer ramus first article (Figure 1) 3 b) U3 inner ramus less than one third of outer ramus first article (Figure 1) 16

3. a) Eyes oval, not higher than $2 \mathrm{x}$ width (Figure 1) 4 b) Eyes "long and narrow", clearly higher than $2 x$ width (Figure 1) 7

4. a) Ventral margin of mandible palp 3rd article: setae not of equal length - producing an uneven fringe. (Peduncle $\mathrm{Al}$ art 2 and 3 subequal in length) Gammarus wilkitzkii Birula, 1897

b) Ventral margin of mandible palp 3rd article: setae of equal length - producing a comb-shaped structure .... 5

5. a) Several plumose setae on P5-7, urosome and telson. Large arctic marine species

.Gammarus setosus Dementieva, 1931

b) No plumose setae on P5-7, urosome and telson.

Boreal fresh water species ... 6

6: a) Ep2 and 3 subequal in shape, hind corner acute. A2 flagellum in $\hat{\sigma}$ without brushes of sensory setae (Figure 1) ...............Gammarus lacustris G. O. Sars, 1863 b) Ep2 and 3 not alike in shape: lower hind corner acute in Ep 3, but not in Ep2. A2 flagellum in $\widehat{O}$ with brushes of sensory setae (Figure 1) Gammarus pulex (L, 1758)

7: a) Ventral margin of mandibular palp art. 3: all setation of similar type, either forming an uneven fringe, or an even comb-like structure 8

b) Ventral margin of mandibular palp art. 3: setae on inner part of margin uneven, on outer part of margin even. (All legs, antenna 2 and uropod 3 are heavily setose with long curled setae)

Gammarus tigrinus Sexton, 1939
8: a) Ventral margin of mandibular palp art. 3: setae not of equal length, forming an uneven fringe .... 9 b) Ventral margin of mandibular palp art. 3: setae of equal length, forming a comb-shaped structure ...... 11

9: a) Al peduncle in $\widehat{O}$ : 3 rd article as long as 2nd article $(>40 \mathrm{~mm}$ ). Large arctic under-ice species (Figure 1) Gammarus wilkitzkii Birula, 1897 b) A1 peduncle in $\delta: 3$ rd article not longer than $50-60 \%$ of 2 nd article $(<25 \mathrm{~mm}$ ) (Figure 1$)$

10: a) P7 article 5: marginal setae obviously longer than spines (Figure 1) ....... Gammarus zaddachi Sexton, 1912 b) P7 article 5: marginal setae not longer than spines; most obviously shorter (Figure 1)

Gammarus salinus Spooner, 1947

11: a) P7 article 2: posterodistal margin with setae only (Figure 1) ............... Gammarus duebenii Liljeborg, 1852 b) P7 article 2: posterodistal margin with both setae and spines (Figure 1) 12

12: a) Al peduncle: 3 setae groups on article 1, 4-5 setae groups on article 2. Mandibular palp ventral margin art. 3: all setae in the "comb" of equal length ..13 b) A1 peduncle: 1-2 setae groups on article 1, 1-2 setae groups on article 2. Mandibular palp ventral margin art. 3: setae in "comb" become gradually longer towards tip of article

13: a) Several plumose setae on P5-7, urosome and telson. P7 basis posterior margin with several long setae. Setae on telson are $3 \mathrm{x}$ as long as the spines. (Figure 2) ............. Gammarus setosus Dementieva, 1931 b) No plumose setae on P5-7, urosome or telson. P7 basis posterior margin with few and short setae. Setae on telson 2x as long as the spines (Figure 2)

Gammarus oceanicus Segerstråle, 1947

14: a) Urosome segments with almost no visible "humps". P7 basis 1.2 - 1.3 times longer than wide Gammarus crinicornis Stock, 1966

b) Urosome segments with clear "humps". P7 basis more than $1.5 \mathrm{x}$ longer than wide

15: a) U3 inner ramus almost as long as outer ramus art. 1 (90-100\%). Ep3 with several setae along hind margin. A2 in $\hat{o}$ with calceoli (Figure 2) Gammarus locusta (L, 1758)

b) U3 inner ramus obviously shorter than outer ramus art. 1 (75-90\%). Ep3 with 0-1 setae along hind margin. A2 in $\widehat{o}$ lacks calceoli (Figure 2) Gammarus inaequicauda Stock, 1966 
16: a) P7 article 2 posterodistal margin with setae only (adults $<10 \mathrm{~mm}$ ). (U3 with almost only spines) (Figure 2) ...... Relictogammarus stoerensis (Reid, 1938) b) P7 article 2 posterodistal margin with both setae and spines (Figure 2)

17: a) A1 peduncle: article 2 as long as article 1. Ep 3 hind corner rounded. (In $\hat{\sigma}$, the "hand" (propodus $\&$ dactylus) is much larger in P1 than in P2. The antennae have long and stiff setae, in every group one of the setae is a lot longer than the rest) (Figure 2) ................... Marinogammarus obtusatus (Dahl, 1938) b) A1 peduncle: article 2 much shorter than article 1. Ep 3 hind corner is rectangular or acute (Figure 2) . 18

18: a) Ep 3: hind corner very acute. A1 peduncle: article 1 shorter than articles $2+3$. Spines on urosome form a continuous arc. U3: outer ramus in $\hat{\jmath}$ without plumose setae, in $q$ with plumose setae on inner margin (Figure 2)

Marinogammarus marinus (Leach, 1815)

b) Ep 3: hind corner rectangular. A1 peduncle: article 1 almost as long as articles $2+3$. Spines on urosomal segment 1 do not form a continuous arc. U3: outer ramus in both $\hat{\sigma}$ and $q$ with plumose setae on inner margin (Figure 2)

....Marinogammarus pirloti Sexton \& Spooner, 1940

\section{A survey of gammarid species in Norway}

The geographic distribution of gammarid species in Norway is not well known, as is the case for many other intertidal amphipods; most of the classical papers on Norwegian amphipods dealt mainly or exclusively with dredged material. In addition, older records can in general not be trusted, as the classification of gammarids has undergone vast changes in the last decades.

The data used in this survey stem from the compilation by Vader et al. (1979, brought up-to-date by Brattegard \& Vader (2018, unpublished)), from our own field observations in western and northern Norway, as well as from papers by Sars (1890-95), Stephensen (1935-42), Dahl (1946), Segerstråle (1947,1954), Spooner (1947), Steen (1951), Oldevig (1959), Brattegard (1966), Dennert (1973), Ingolfsson (1977), Palerud et al (2004), and a series of papers on freshwater gammarids by Økland (1965, 1969, 1970, 2011a,b). For the ecological data we have relied mostly on data from Western Europe, the series of papers from Newfoundland by Steele \& V. Steele (1969, 1970, 1972, 1975; V. Steele \& Steele 1970, 1972), and the Oslofjord studies of Skadsheim (1982, 1983, 1984). There has been much research also in the Baltic, but the situation there, with a lowered, but more or less constant salinity, is quite different from the situation in the intertidal, estuaries and pollens in Norway with their very changeable salinity.
In this survey we have divided the gammarids of Norway into 8 groups. We have deviated from the traditional grouping on two points: we have joined Gammarus oceanicus (although originally described as a subspecies of $G$. zaddachi) with G. setosus, and also G. duebenii with Marinogammarus finmarchicus.

Gammarus oceanicus and G. setosus are both uniformly coloured species with a northerly and amphi-atlantic distribution, while G. zaddachi and G. salinus are striped animals with a more southerly and purely eastern Atlantic distribution.

Similarly G. duebenii and ?M. finmarchicus show many morphological and ecological similarities. The final taxonomic position of finmarchicus is still unclear, and many authors place it in Gammarus, close to G. duebenii.

\section{A. Gammarus locusta group}

In the older literature, also in Norway, practically all fully marine Gammarus were called G. locusta, although Sars (189095) realized there was a different species, which he called G. campylops. In 1967 Stock revised the Gammarus locusta group, and i.e. described four species from northern Europe, two of which have been found also in Norwegian waters; $G$. locusta s. str. and G. inaequicauda (=Sars's campylops, but not campylops Leach), while a third, G. crinicornis, may still be found in the SW.

All the species in this group are mainly sublittoral boreal marine or brackish water forms.

\section{Gammarus locusta (Linnaeus, 1758)}

Descriptions and illustrations: Sexton 1942, pl. 3 figs 19-24; Spooner 1947, p. 7, figs 1, 2 A-B, 3; Kinne 1954, p. 409, figs 1-2pp, 4-6; Stock 1967, p. 11, fig. 1.

Ecology and habitat: A marine, mainly sublittoral species of the algal belt, tolerates some lowering of the salinity, but not much, unless it is stable, as in the Baltic. Not often found in the intertidal during ebb. A useful review is Costa \& Costa (2000)

A very special case was the situation in Rauneforden near Bergen, where large amounts of kelp (mainly Laminaria) washed down to the bottom at $240 \mathrm{~m}$. In this biotope Gammarus locusta was surprisingly common, and the animals grew very large (Vader, unpubl. obs.).

Distribution in Norway: Not really well known because of earlier confusion, mainly with $G$. oceanicus, and the fact that this species mainly lives on the outer coast and largely sublittorally. Occurs quite commonly along the entire South and West coast, much more sparingly east of the North Cape. It does not penetrate into the fjords much, and in the North it is restricted to the outer coast. Surprisingly, recent studies have found the species present in Kongsfjorden, Svalbard (Berge \& Shunatova, pers. comm.) 

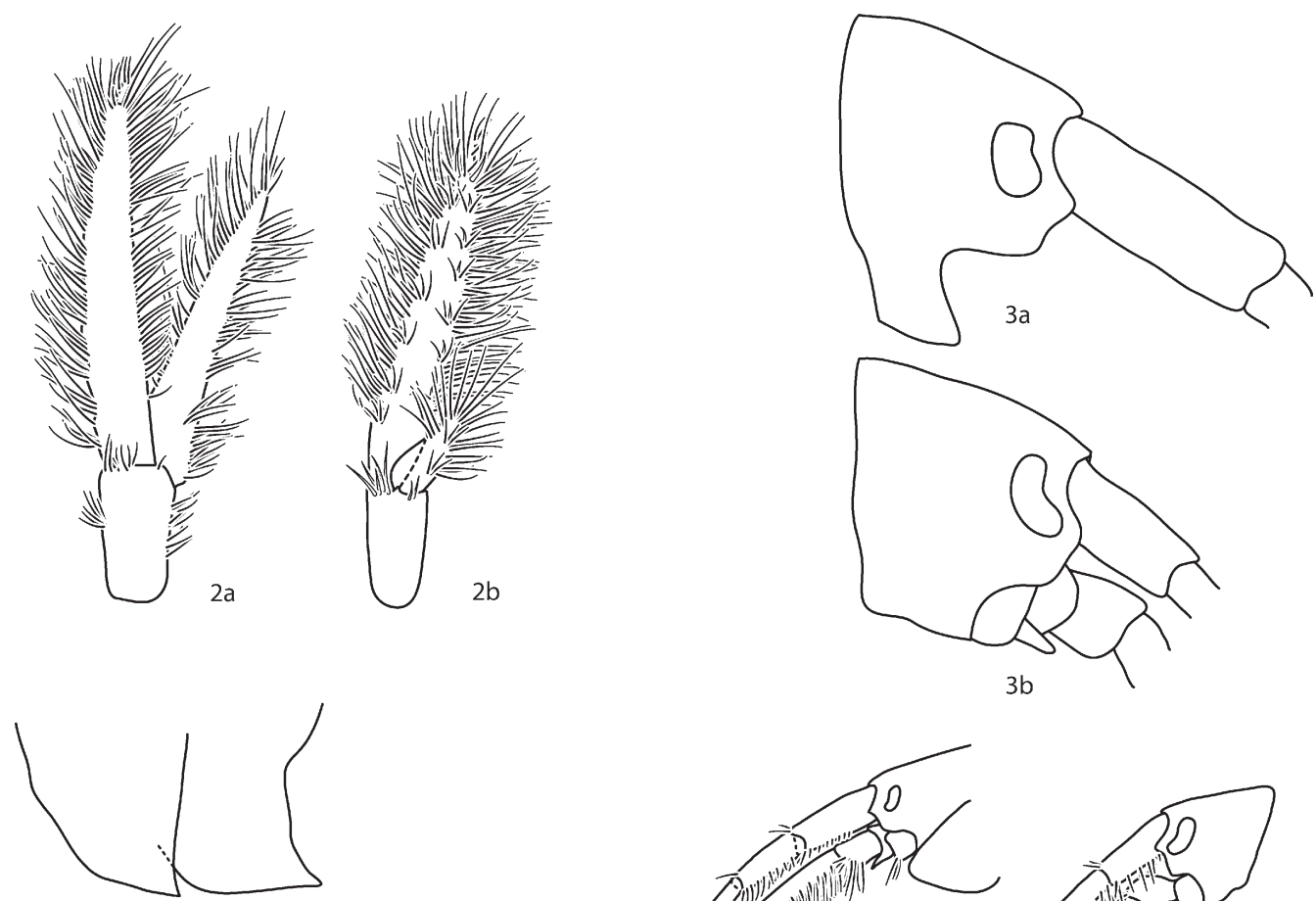

$6 a$

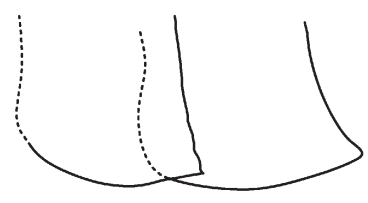

$6 b$
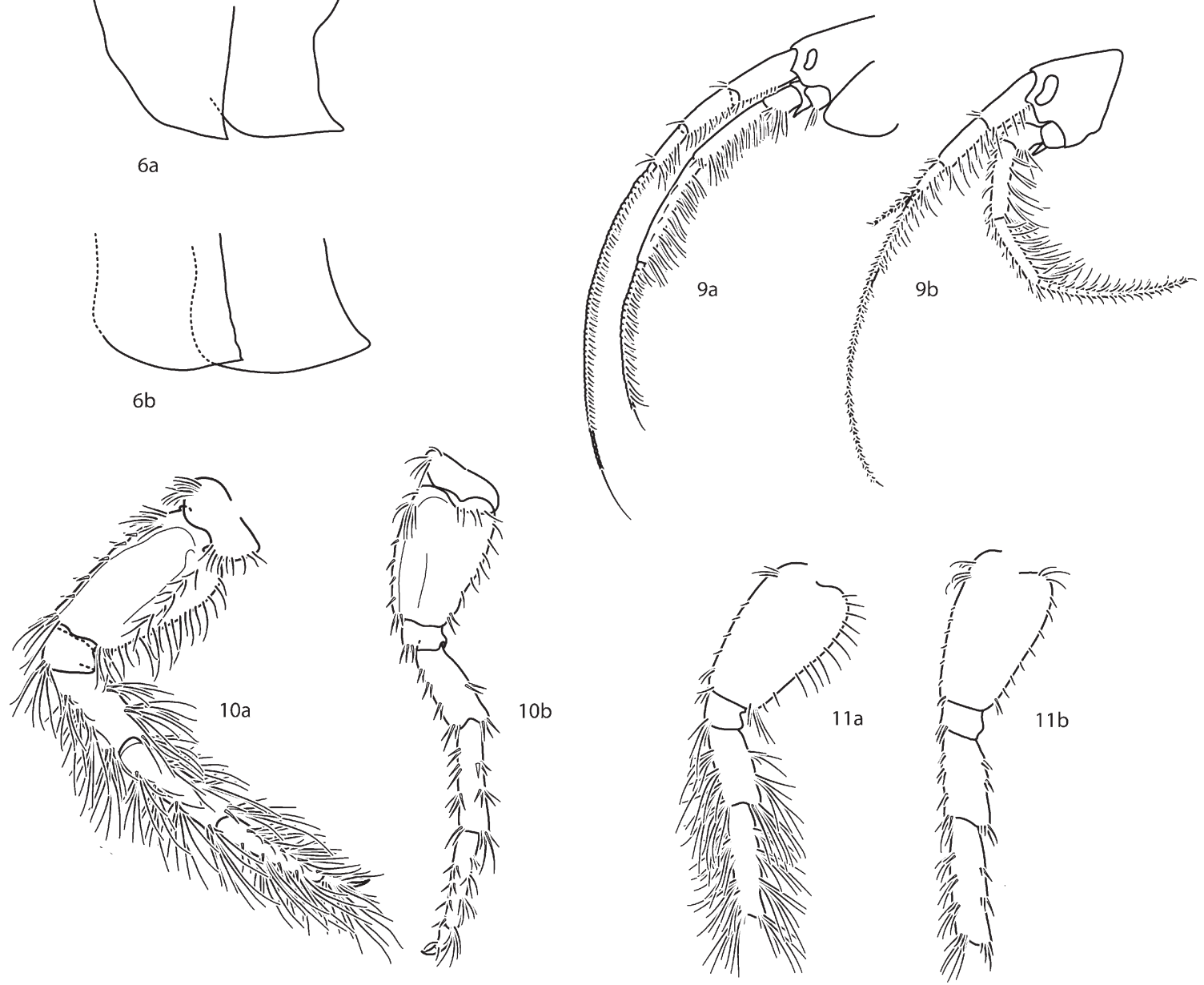

Figure I. Illustrations to questions 2, 3, 6, 9, 10 and 11 from the key. 2a: Marinogammarus marinus illustration from Sexton \& Spooner (1940). 2b: Gammarus wilkitzkii illustration from Barnard (1959). 3a: Gammarus wilkitzkii illustration from Barnard (1959). 3b: Gammarus tigrinis illustration from Lincoln (1979). 6a: Gammarus lacustris illustration from Økland (1969). 6b: Gammarus pulex illustration from Pinkster (1970). 9a: Gammarus wilkitzkii illustration from Barnard (1959). 9b: Gammarus salinus illustration from Lincoln (1979). 10a: Gammarus zaddachi illustration from Sexton (1942). 10b: Gammarus salinus illustration from Sexton (1942). 11a: Gammarus duebenii illustration from Lincoln (1979). 11b: Gammarus oceanicus illustration from Lincoln (1979). 

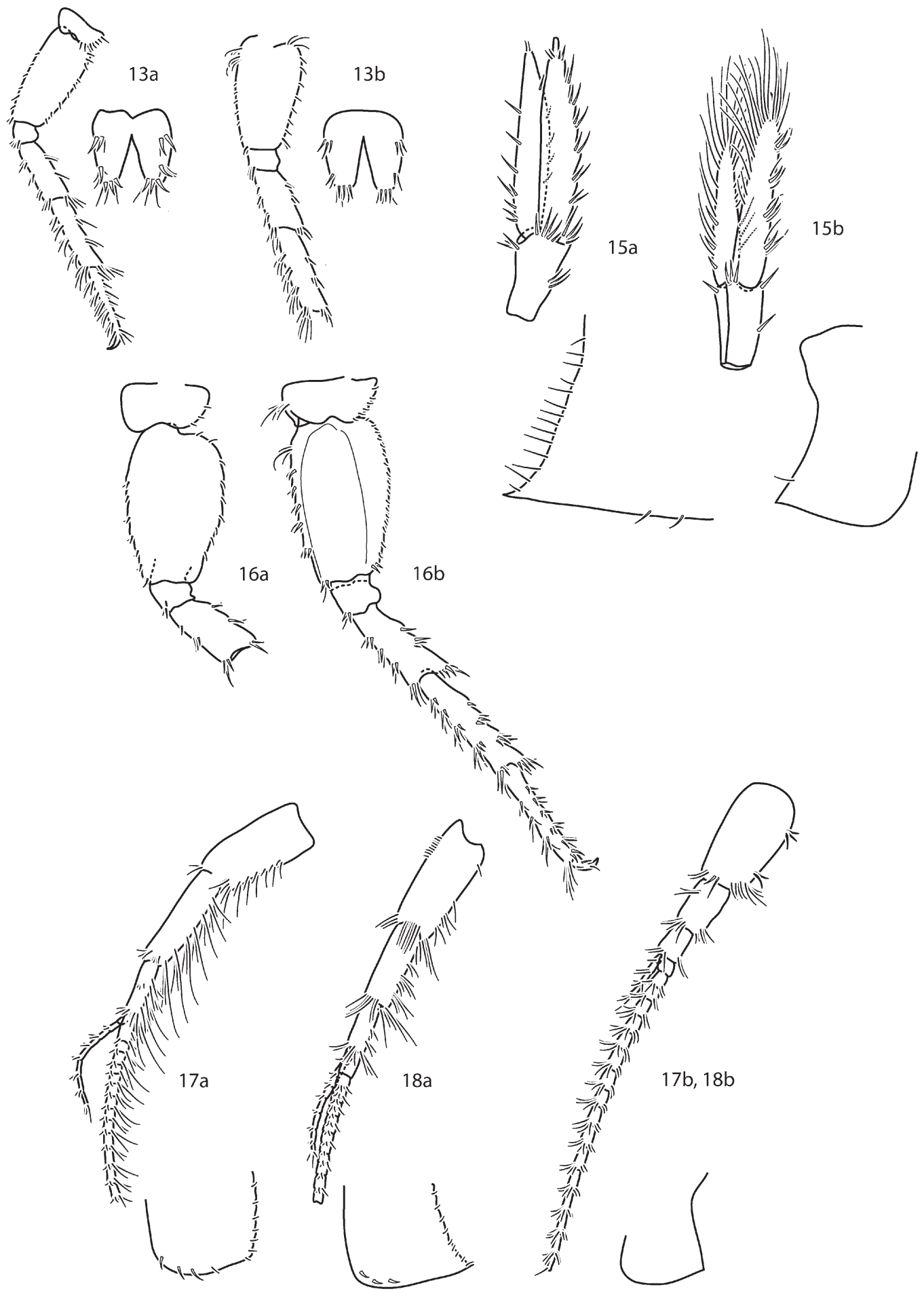

$16 b$

Figure 2. Illustrations to questions 13, 15, 16, 17 and 18 from the key. 13a: Gammarus setosus illustration from Bousfield (1973). 13b: Gammarus oceanicus illustration from Lincoln (1979). 15a: Gammarus locusta illustration from Lincoln (1979). 15b: Gammarus inaequicauda illustration from Sars (1890-95). 16a: Relictogammarus stoerensis illustration from Sexton \& Spooner (1940). 16b: Marinogammarus marinus illustration from Sexton \& Spooner (1940). 17a: Marinogammarus obtusatus illustration from Sexton \& Spooner (1940). 18a: Marinogammarus marinus illustration from Sexton \& Spooner (1940). 17b and 18b: Marinogammarus pirloti illustration from Sexton \& Spooner (1940). 


\section{Gammarus crinicornis Stock, 1966}

Synonyms: Gammarus plumicornis s. Pirlot (1939) and den Hartog (1964); non G. plumicornis Costa, 1853

Description and illustrations: Pirlot 1939, p. 54, figs 4-7 (as G. plumicornis); Stock 1967, p. 32, figs 14-16; Lincoln 1979, p. 263, fig 121 .

Ecology and habitat: A marine, mainly sublittoral species, often from sandy bottoms with many loose algae. In the Netherlands often in the surf zone off sandy beaches (Vader, unpubl. obs.). Not found in brackish water.

Distribution: Not well known, not yet found in Norway. Occurs from W. Africa along the coasts to S. England and the Netherlands, also in the Mediterranean.

\section{Gammarus inaequicauda Stock, 1966}

Synonyms: Gamnmarus campylops s. Sars (1890-95); non G. campylops Leach, 1815. This species is very close to $G$. insensibilis Stock, 1966

Descriptions and illustrations: Sars 1890-95, p. 500, pl. 176-2 (as G. campylops); Stock \& Kant 1966, pp 9-11, figs 1-2.; Stock 1967, p. 22, figs 7-8.

Ecology and habitat: In Norway, this is a species of the shallow subtidal in protected, often densely vegetated areas of somewhat varying salinity. The intertidal in these areas is generally occupied by other Gammarus species, often $G$. salinus.

Distribution in Norway: This species was originally described from Moss in the Oslo fjord. Its distribution is not yet fully known, but it seems to be quite widespread in the right biotopes along the south coast (Vader et al. 1984). Outside Norway, the only records still seem to be from Poland (Jazdzewski 1970)

\section{B. Gammarus oceanicus group.}

This is a group of quite large, unicoloured, basically marine Gammarus species, with a northerly and amphi-atlantic distribution. They are basically sublittoral, but are found more often intertidally than the species in group A, especially in the far north. Along the Norwegian coast they live primarily among algae, but in Arctic areas they are often found in Marinogammarus-like biotopes, intertidally below stones.

\section{Gammarus oceanicus Segerstråle, 1947}

Synonyms: Gammarus zaddachi oceanicus auct.; Lagunogammarus oceanicus auct.

Descriptions and illustrations: Segerstråle 1947, p. 226, fig. 3 a-g; Spooner 1951, p. 130; Dunbar 1954, p. 765, fig. 31; Kinne 1954, p. 414, figs1-2, 4pp; Lincoln 1979, pp 243, 253, figs 100e, 111c, 119.

Biology: Along the south and west coast and in the large fjords of western Norway this is a species of the low intertidal and shallow subtidal, where it is primarily found in the algal belt of Fucaceae and is generally very common. In Northern Norway, and still more characteristically in Svalbard, this species is also very often found under stones in the lower intertidal, even on mudflats with occasional algae-covered large stones (Weslawski 1994).

Distribution in Norway: This is probably the most numerous Gammarus species on the Norwegian coast, where it also penetrates far into the fjords (Brattegard 1966, Vader 1977a). G. oceanicus is also common in Svalbard waters, but it is absent from the southern North Sea. It has recently been found further north than earlier in Svalbard waters, probably as a result of global warming (Węsławski et al. 2018)

\section{Gammarus setosus Dementieva, 1931}

Synonym: Lagunogammarus setosus auct.

Description and illustrations: Stephensen 1935-42, p. 321, fig. 41; Segerstråle 1947, p. 241, fig. 7; Christiansen 1965, fig. 3; Bousfield 1973, p. 50, pl. 1-2.

Biology: A mostly arctic marine, largely intertidal species. In the Arctic (Weslawski 1994), and also in Iceland (Ingolfsson 1977), this species is often found intertidally under stones, generally above the zone populated by $G$. oceanicus. In Newfoundland G. setosus is only found in the outlets of cool fresh-water streams in summer (V. Steele \& Steele 1970), and this is precisely the biotope in which we have found this species in Finnmark, where it is found in the larger rivers, usually below the waterline.

Distribution in Norway: This is basically an Arctic species, and it has been reported from only a few places in Northern Norway (Malangen, Hammerfest, Tana) (Vader 1977b); a record from the Oslofjord (Stephensen 1935-42, p. 323) we consider doubtful. The species has an amphi-atlantic, high northern distribution, and is common on Svalbard.

\section{The Gammarus zaddachi group}

The three species G. zaddachi, G. salinus and G. wilkitzkii appear to be closely related morphologically, zoogeographically and ecologically; however, the 'under-ice high-arctic' $G$. wilkitzkii seems quite different from the other two, that are confined to a quite restricted area in northwestern Europe: south to western France (Bretagne). All three are basically brackish water species. G. zaddachi and G. salinus are easily recognized compared to the species in groups $\mathrm{A}$ and $\mathrm{B}$ because of their colour pattern; they have a clear pattern of transverse dark stripes on a light brown background. 
6. Gammarus zaddachi Sexton, 1912 (s. Spooner, 1947)

Synonyms: Gammarus zaddachi zaddachi auct.; G. setosus balticus Dementieva, 1931; G. sarsi Reid, 1939; G. ochlos Reid, 1945; Lagunogammarus zaddachi auct.

Descriptions and illustrations: Sexton 1942, p. 593, pl. 1, figs 1-7, pl. 2, figs 10-14 (as G. zaddachi, freshwater form); Segerstråle 1947, p. 231, figs 3h-j, 5; Spooner 1947, p. 20, figs 4A-B, 5A-C; Kinne 1954, p. 417, figs 1- 4pp; Dennert et al. 1969, p. 23; Lincoln 1979, pp 239, 243, 249, figs 110a, 111a-b, 114.

Ecology and habitat: Gammarus zaddachi is a brackish water amphipod, living subtidally or in the lower intertidal. It is quite common in the lower intertidal in the inner fjords (where G. duebenii occupies the upper intertidal), but on the outer coast it is generally confined to river mouths (Vader 1977a-b). Also there it lives mainly in the lower intertidal or shallow subtidal, while G. duebenii occupies the higher intertidal. Compared to areas further south (den Hartog 1964, Spooner 1947) G. zaddachi in Norway seems to occupy somewhat less saline waters. Migratory movements, quite conspicuous in French estuaries (Dennert et al. 1969, Stock 1966, Girisch et al. 1974), have not yet been studied in Norway.

Distribution in Norway: Gammarus zaddachi occurs all along the Norwegian coast, in the right biotopes (Brattegard 1966, Dennert 1973, Vader 1977a-b). On the open coast it is restricted to the outlet of minor streamlets, where it may penetrate quite far inland (Vader 1977b). In the inner parts of the large fjords, often meso- or even oligohaline, G. zaddachi becomes the dominant amphipod in the lower intertidal, often together with G. oceanicus (Brattegard 1966, Vader 1977a). The species is absent from Svalbard.

A very aberrant biotope was discovered by the Økland family (Økland et al. 2011): a population of G. zaddachi lives at $150 \mathrm{~m}$ depth in the freshwater lake Eikeren in inland southern Norway.

\section{Gammarus salinus Spooner, 1947}

Synonyms: Gammarus zaddachi salinus auct.; Lagunogammarus salinus auct.

Descriptions and illustrations: Sexton 1942, pl. 1, figs 8, 9, pl. 2, figs 15-18 (as G. zaddachi, saline form); Spooner 1947, p. 20. figs 4C, 5D-E; Kinne 1954, p. 416, figs 1-4pp; Dennert et al. 1969, p. 23; Lincoln 1979, pp 243, 251, figs 111f, 115.

Ecology and habitat: Elsewhere in Europe Gammarus salinus is known as the species concentrated in the areas with the largest oscillations in salinity (den Hartog 1964, Movaghar 1964, Meurs \& Zauke 1988); this is in agreement with the situation in the inner Oslofjord (Skadsheim 1983). Here G. salinus lives in the lower intertidal, while the records from the south coast and the Bergen area mostly concern the shallow subtidal, as in the estuaries of Western Europe (Spooner 1947, den Hartog 1964), although also there the species may occur intertidally under special circumstances, usually involving lowered salinity (Vader 1965).

Distribution in Norway: Not well known. The species is common in the inner part of the Oslofjord (Skadsheim 1983, 1984), and it has also been found along the south coast (Dennert 1973, Vader et al. 1984). In the Hardangerfjord Brattegard (1966) found G. salinus only in the side fjords, while the northernmost records hitherto are from the Bergen area (Vader 1972). Vader (1977a) did not find G. salinus at all in the Sognefjord. G. salinus is a southern species, occurring along European coasts south to N. Spain (van Maren 1975); it is absent from Iceland (Ingolfsson 1977).

\section{Gammarus wilkitzkii Birula, 1897}

Synonym: Lagunogammarus wilkitzkii auct.

Descriptions and illustrations: Sexton 1942, p. 601; Gurjanova 1951, p. 764, fig. 551; Barnard 1959, p. 120, pls 10-13.

Ecology and habitat: This large and slow-growing species occurs primarily in the pack ice (Weslawski 1994), where it is omnivorous (Arndt 2002). In areas with seasonal ice cover the animals may live benthically in the ice free periods (Arndt et al. 2005).

Distribution: This is a high-arctic species, occurring along the coasts of Siberia and northern Canada, as well as in the pack ice of the Polar Sea. It has never yet been found in Norwegian waters outside Svalbard. Svalbard distribution is mapped by Węsławski et al. (2018).

\section{The Gammarus tigrinus group}

\section{Gammarus tigrinus Sexton, 1939}

Description and illustrations: Sexton 1939, pp 545-548, pls IV-VI; Bousfield 1973, pp 51-52p. 50, pl. IV-14; Lincoln 1979, p. 254, fig. 117.

This species belongs to a group of primarily American brackish- and fresh-water Gammarus species, which in many ways parallel the G. zaddachi group in Europe, i.a. by their conspicuous ‘tiger stripes' (cf e.g. Bousfield 1969). G. tigrinus has no doubt been imported to Europe by man, but when and where is unknown. It was first discovered in Britain in the 1930's and described as a new species by Sexton (1939). It was later recognized as identical to certain populations of the American freshwater species G. fasciatus Say, 1818 but this species was split by Bousfield (1958), with the brackish water populations retaining the name G. tigrinus. Later it was imported by fisheries people to both the Netherlands and Germany, in the hope that this would increase the food basis for freshwater fish; instead the species quickly developed into a problem (see i.e. Ruoff 1968). Its dispersal in the Netherlands 
has been followed in detail over the years, and it is clear that $G$. tigrinus is completely dominant to the indigenous Gammarus species in many habitats; it is i.e. less sensitive to pollution (see e.g. Nijssen \& Stock 1966, Gras 1971).

Ecology and habitat: In the USA Gammarus tigrinus is a species of oligohaline and mesohaline habitats in estuaries. In Europe it is found in similar biotopes, e.g. in the Baltic Sea, but also in stagnant oligohaline brackish and even in fresh water, where it often has ousted the local indigenous Gammarus species.

Distribution: In Europe hitherto found in Ireland, Britain, Holland, Germany and the Baltic Sea. Gammarus tigrinus has not yet been recorded from Norway.

\section{E. The Gammarus lacustris group.}

This group contains the pure freshwater species. Morphologically the group is characterized by short oval eyes, and a short inner ramus of uropod 3. The two Nordic species are probably not especially closely related. G. lacustris has a holarctic distribution, while G. pulex is exclusively palaearctic.

NB. The genus name Rivulogammarus S. Karaman, 1931, often used for this group, is unavailable (Stock, 1969a).

\section{Gammarus lacustris Sars, 1863}

Synonyms: Rivulogammarus lacustris auct.; Gammarus pulex sensu Sars (1890-95); non Cancer pulex Linnaeus, 1758; Rivulogammarus scandinavicus S. Karaman, 1931.

Description and illustrations: Sars 1890-95, p. 503, pl. 177-2 (as G. pulex); Økland 1969, p. 132, figs 16-23.

Ecology and habitat: Dealt with in detail by Økland (1969). G. lacustris lives in lakes, ponds and slow moving rivers at places where the water is not too acidic and too deficient in calcium.

Distribution: See Segerstråle (1954) and Økland (1969, fig.2). This species occurs in most of Norway, but has not been reported from Østfold and Agder, while there are no reports from Lofoten-Vesterålen either. Around Bergen G. lacustris has been recently discovered by Bjerknes (pers. comm.). Outside Norway, G. lacustris has a very wide holarctic distribution at northerly latitudes.

\section{Gammarus pulex (Linnaeus, 1758)}

Synonyms: Rivulogammarus pulex auct.; Gammarus pulex pulex auct.

Description and illustrations: Schellenberg 1942, pp 2426, figs 6b, 7, 8 (as G. p. pulex); Pinkster 1970, pp 181, 183, 185, figs1 p. 179, figs 1-4.

Ecology and habitat: Character species of rivers with not too strong currents, but it can also live in stagnant ditches and pools, and even in oligohaline brackish water.

Distribution: The Scandinavian distribution has been mapped by Segerstråle (1954). Gammarus pulex has in Sweden been found close to the border of Østfold in SE Norway, but as yet there are no Norwegian records.

\section{F. The Gammarus duebenii group}

Here we have combined G. duebenii and Marinogammarus finmarchicus, both somewhat odd man out in their genus, both morphologically and ecologically. Both are largely intertidal species, although duebenii has a much wider ecological tolerance, and both have an amphi-atlantic distribution. (Pinkster et al. (1970) split off the freshwater populations in Ireland and Brittany as G.d. celticus; this taxon is not considered here). In contradistinction to the species in the zaddachi and tigrinus groups, these species are not patterned, but unicoloured.

\section{Gammarus duebenii Liljeborg, 1852}

Synonyms: Rivulogammarus duebenii auct. (NB. The specific epithet is often written duebeni, and the author's name Lilljeborg; both are incorrect.).

Description and illustrations: Sars 1890-95, p. 507, pl. 177-1; Kinne 1954, p. 419, figs 1-4pp; Lincoln 1979, pp 243, 245, figs 111e, 112.

Ecology and habitat: Gammarus duebenii is a very euryoecious species, and generally one can say that it occurs everywhere where other Gammarus and Marinogammarus species do not thrive (see e.g. Forsman 1951, Kinne 1953, den Hartog 1964). In Norway the main biotope is supralittoral rockpools, the mouth of small and medium large streamlets (here they can ascend quite a bit upstream and live at least temporarily in pure freshwater), and intertidally, under stones and among algae in meso- and oligohaline brackish waters, as in the inner part of fjords (Brattegard 1966, Vader 1977a).

Gammarus duebenii has also several times been found in 'freshwater' lakes and pools in Norway (see Økland 1970, Kjærstad et al. 2016). As 'marflo' samples are often transported by fishermen between lakes and even from the shore to lakes, some of these occurrences may be not quite natural.

Distribution. Common along the whole coast of Norway, but absent from Svalbard waters. A few freshwater occurrences.

\section{Marinogammarus finmarchicus (Dahl, 1938)}

Synonyms: Gammarus finmarchicus auct.; Chaetogammarus finmarchicus auct; Gammarus greenfieldi Shoemaker, 1938; Echinogammarus finmarchicus auct.

Description and illustrations: Dahl 1938, p. 125, figs 1-10 (Gammarus f.); Stephensen 1935-42, p. 344, figs 45-46 p.p.; Sexton \& Spooner 1940, p. 656, figs 6,7; Bousfield 1973, p. 
58, pl. 7; Lincoln 1979, pp 238, 243, 247, figs 110d, 111g, 113 (Gammarus f.)

Ecology and habitat: Under stones in the lower intertidal, preferably where some water remains at low tide. Penetrates to a certain distance in fjords: in Hardanger to indre Samlafjorden (Brattegard 1966), in the Sognefjord to Helle (Vader 1977a).

Distribution: Common along most of the Norwegian coast (not in Svalbard), but there are few records as yet from the Skagerrak coast.

\section{G. The Marinogammarus group}

All Marinogammarus species are marine and occur mostly intertidally, usually more under stones or in gravel than among algae. Even though one may find several species closely together, the species nevertheless differ in their specific demands. This may lead to a microsegregation, even when present below the same boulder. An example is shown by a study in the Netherlands (Vader 1965) from a sandy beach with scattered large stones and some freshwater flow. Here Gammarus salinus kept to the free water puddles, Marinogammarus obtusatus lived in clumps of Mytilus above the water, and Relictogammarus stoerensis in the gravel and sand; three species below the same boulder, but still in different habitats!

There are no Marinogammarus species on Svalbard. Their role in the intertidal is there taken over by Gammarus setosus and to a certain degree G. oceanicus. In mesohaline and oligohaline areas, and high in the intertidal, G. duebenii takes over the 'under stones' habitat.

\section{Marinogammarus marinus (Leach, 1815)}

Synonyms: Gammarus marinus auct; Chaetogammarus marinus auct; Echinogammarus marinus auct.

Description and illustrations: Stephensen 1935-42, p. 340, figs 45-46pp; Sexton \& Spooner 1940, p. 638, figs 1-2; Lincoln 1979, pp 265, 267, figs 122a, 123 (Chaetogammarus m.).

Ecology and habitat: This is the most euryoecious of the Marinogammarus species. Usually it is to be found under stones in the upper half of the intertidal. In places with some freshwater flow, or where M. obtusatus and/or? ?M. finmarchicus for some reason are absent, it may occur lower down. M. marinus tolerates more sediment in the substrate than the other species, and it also occurs in brackish waters. In estuaries it occurs far into the mesohalinicum (den Hartog 1964). In the fjords in W. Norway it penetrates very far: in Hardanger until Osafjorden (Brattegard 1966), in the Sognefjord far into the Lusterfjord (Vader 1977a).

Distribution in Norway: Very common everywhere in southern Norway. Its distribution is insufficiently known in northern Norway: it is not rare around Tromsø, but we know of no reliable records east of the North Cape.

\section{Marinogammarus obtusatus (Dahl, 1938)}

Synonyms: Chaetogammarus obtusatus auct.; Eulimnogammarus obtusatus auct.; Echinogammarus obtusatus auct.

Description and illustrations: Dahl 1938, p. 127 (as Gammarus o.), figs 11-21; Stephensen 1935-42, figs 45-46pp; Sexton \& Spooner 1940, p. 650, fig.5; Pinkster \& Stock 1970, p. 207, figs 2 a-g (Eulimnogammarus o.); Lincoln 1979, p. 273, fig. 126 (Eulimnogammarus o.).

Ecology and habitat: Under stones in the lower intertidal, preferably on a substrate of sand, gravel, or shells; occurs also on intertidal pebble beaches. Tolerates some freshwater flow, but not much fine sediment. Penetrates less far into fjords than ?M finmarchicus: in Hardanger to Samlafjorden (Brattegard 1966), in the Sognefjord to Lavik (Vader 1977a)

Distribution in Norway: Probably occurs along the entire Norwegian coast, but absent in Svalbard.

\section{Marinogammarus pirloti Sexton \& Spooner, 1940}

Synonyms: Chaetogammarus pirloti auct.; Echinogammarus pirloti auct.

Description and illustrations: Sexton \& Spooner 1940, p. 667, figs 9-10, pl. 4; Lincoln 1979, pp 265-269, figs 122b, 124 (Chaetogammarus p.).

Ecology and habitat: Intertidally, under stones and among algae (Ascophyllum, Enteromorpha) at places where freshwater flows out. Distribution very patchy, but may be numerous where occurring. Apparently confined to the outer coast.

Distribution in Norway: Not well known. Discovered in Norway by Tulkki (1963) in the outermost Hardangerfjord. Later once found in the Oslofjord (C. Christophersen, pers. comm.) and a few places between Hardanger and the outer Trondheimsford (Vader 1969), in all cases close to the open coast, as is also the case in Britain (Spooner 1957). Not yet found further north than the Trondheimsfjord, but may well occur there.

\section{H. The Relictogammarus group}

This consists of only the small species $R$. stoerensis, which according to the studies of Hou \& Sket (2016) should be considered the sister group to all other Gammaridae.

\section{Relictogammarus stoerensis (Reid, 1938)}

Synonyms: Gammarus stoerensis Reid, 1938; Marinogammarus stoerensis auct.; Chaetogammarus stoerensis auct.; Echinogammarus stoerensis auct.

Description and illustrations: Stephensen 1935-42, p. 346. fig. 49 (Marinogammarus st.); Sexton \& Spooner 1940, p. 662, fig. 8 (Marinogammarus st.); Lincoln 1979, p. 271, fig. 125 


\section{(Chaetogammarus st.).}

Ecology and habitat: Intertidal, under stones and in gravel, coarse mud-intermixed sand or other mixed fine substrate, at places where lesser amounts of freshwater flow out. The vertical distribution covers almost the entire intertidal, down from MHWN; higher up it is often replaced by Gammarus duebenii. $R$. stoerensis tolerates much brackish water; in the Sognefjord the first author (Vader 1977a) found them at Dale in the Lusterfjord, where the fjord is ice-covered several months each winter. In the inner fjords $R$. stoerensis may be almost dominant some places (cf Skadsheim 1983) and it is there, where the salinity is very variable during the year, much less confined to freshwater trickles.

Distribution in Norway: Probably common along the entire Norwegian coast, but absent from Svalbard. There are as yet few records from N. Finnmark (Vader 1971), but the species also occurs in the Murmansk region (Segerstråle 1948).

\section{ACKNOWLEDGEMENTS}

This work was financed through Artsdatabanken project NorAmph (Artsprosjekt 46-15). The manuscript has been improved by the helpful reviews by Jan Marcin Weslawski, Torkild Bakken and one anonymous reviewer.

\section{REFERENCES}

Arndt CL. 2002. Feeding ecology of the Arctic ice-amphipod Gammarus wilkitzkii - physiological, morphological and ecological studies. Berichte zur Polar- und Meeresforschung 405: 1-74. doi: 10.2312/BzPM_0405_2002

Arndt CE, Fernandez-Laborans G, Seuthe L, Berge J. 2005. Ciliated epibionts on the Arctic sympagic amphipod Gammarus wilkizkii as indicators for sympago-benthic coupling. Marine Biology 147: 643-652. doi: 10.1007/s00227-005-1599-4

Barnard JL. 1959. Epipelagic and under-ice Amphipoda of the Central Arctic Basin. Geophysical Research Papers 63: 115-152.

Birula AA. 1897. (Recherches sur la biologie et zoogéographie principalement des mers russes: 2. Hydrozoa, Polychaeta et Crustacea, etc). Annuaire de Musée Zoologique de l'Académie Imperiale des Sciences de St.-Petersbourg 2:78-116 (In Russian).

Boeck A. 1861. Bemærkninger angaaende de ved de norske Kyster forekommende Amphipoder. Forhandlinger ved de Skandinaviske Naturforskeres 8. Møte 1860: 631-677.

Bousfield EL. 1958. Fresh-water amphipod crustaceans of glaciated North America. Canadian Field Naturalist 72: 55-113.

Bousfield EL. 1969. New records of Gammarus (Crustacea: Amphipoda) from the Middle Atlantic Region. Chesapeake Science 10: 1-17.

Bousfield EL. 1973. Shallow-water Gammaridean Amphipoda of New England. Cornell University Press, Ithaca \& London. 312pp, $69 \mathrm{Pls}$.

Brattegard T. 1966. The natural history of the Hardangerfjord 7. Horizontal distribution of the fauna of rocky shores. Sarsia 22:
$1-54$.

Christiansen BO. 1965. Notes of the littoral fauna of Bear Island. Astarte 1(26): 1-15.

Costa FO, Costa MH. 2000. Review of the ecology of Gammarus locusta (L.). Polskie Archiwum Hydrobiologii 47: 541-559.

Dahl E. 1938. Two new Amphipoda of the genus Gammarus from Finnmark. Kongelige Norske Videnskaps Selskaps Forhandlinger 10: 125-128.

Dahl E. 1946. Zoologiska intryck från en vår i Nordnorge. Fauna Flora, Uppsala (1946): 256-282.

Dementieva T. 1931. On the variability of the Amphipoda of the Northern Seas. Transactions of the Oceanographic Institute Moscow 2-3: 65-82.

Dennert HG. 1973. Notes on some euryhaline gammarids (Crustacea, Amphipoda) from the west coast of Norway. Bijdragen tot de Dierkunde 43: 160-172.

Dennert HG, Dennert AL, Kant P, Pinkster S, Stock JH. 1969. Upstream and downstream migrations in relation to the reproductive cycle and to environmental factors in the amphipod, Gammarus zaddachi. Bijdragen tot de Dierkunde 39: $11-43$

Dunbar MJ. 1954. The amphipod Crustacea of Ungava Bay, Canadian Eastern Arctic. Journal of the Fishery Research Board Canada 11(6): 709-798.

Forsman B. 1951. Studies of Gammarus duebeni Lillj., with notes on some rockpool organisms in Sweden. Zoologiska Bidrag från Uppsala 29: 215-237.

Girisch HB, Dieleman JC, Petersen W, Pinkster S. 1974. The migration of two sympatric gammarid species in a French estuary. Bijdragen tot de Dierkunde 44: 239-273.

Gledhill T, Sutcliffe DW, Williams WD. 1976. Key to British freshwater Crustacea: Malacostraca. Freshwater Biological Association Scientific Publication 31: 1-71.

Gras JMJF. 1971. Range extension in the period 1968-1970 of the alien amphipod, Gammarus tigrinus Sexton, 1939, in the Netherlands. Bulletin Zoologisch Museum, Universiteit Amsterdam 2: 5-9.

Gurjanova E. 1930. Beiträge zur Fauna der Crustacea Malacostraca des Arktischen Gebietes. Zoologischer Anzeiger 86: 231-248.

Gurjanova EF. 1951. Bokoplay morej SSSR i sopredel 'nykh vod (Amphipoda - Gammaridea). Akad. Nauk SSSR Opredel. Faune SSSR 41: 1-1031.

Hartog C den. 1964. The amphipods of the Deltaic region of the rivers Rhine, Meuse and Scheldt in relation to the hydrography of the area. Part 3: The Gammaridae. Netherlands Journal of Sea Research 2: 407-457.

Horton T, Lowry J, De Broyer C, Bellan-Santini D, Coleman CO, Corbari L, Costello MJ, Daneliya,M, Dauvin J-C, Fišer C, Gasca R, Grabowski M, Guerra-García,JM, Hendrycks E, Hughes L, Jaume D, Jazdzewski K, Kim Y-H, King R, Krapp-Schickel T, LeCroy S, Lörz A-N, Mamos T, Senna A R, Serejo C, Sket B, Souza-Filho JF, Tandberg AH, Thomas J, Thurston M, Vader W, Väinölä R, Vonk R, White K, Zeidler W. 2018. World Amphipoda Database. Gammaridae Leach, 1814. Accessed at: http://www.marinespecies.org/amphipoda/aphia. php? $\mathrm{p}=$ taxdetails\&id=101383 on 2019-02-05

Hou Z, Sket B. 2016. A review of Gammaridae (Crustacea: Amphipoda): the family extent, its evolutionary history, and taxonomic redefinition of genera. Zoological Journal of the 
Linnean Society 176: 323-348. doi: 10.1111/zoj.12318

Hynes HBN, Macan TT, Williams WD. 1960. A key to the British species of Crustacea: Malacostraca occurring in fresh water. Freshwater Biological Association, Scientific Publications 19: 1-36.

Ingolfsson A. 1977. Distribution and habitat of some intertidal amphipods in Iceland. Acta Naturalia Islandica 25: 1-28.

Jazdzewski K. 1970. Gammarus inaequicauda Stock in the Baltic Sea (Amphipoda, Gammaroidea). Crustaceana 19: 216-217.

Karaman S. 1931. III. Beitrag zur Kenntnis der Amphipoden Jugoslawiens, sowie einiger Arten aus Griechenland. Prirodos RazpraveovnePrirodosovne Razprave 1: 31-661.

Kinne O. 1954. Die Gammarus-Arten der Kieler Bucht ( $G$. locusta, G. oceanicus, G. salinus, G. zaddachi, G. duebeni.). Zoologisches Jahrbuch Systematik 82: 405-424.

Kjærstad G, Koksvik JI, Arnekleiv JV. 2016. Funn av brakkvannstangloppen Gammarus duebeni (Crustacea, Amphipoda) i ferskvann. Fauna 69: 114-118.

Leach, WE. 1815. A tabular view of the external characters of four classes of animals, which Linné arranged under insects; with the distribution of the genera composing three of these classes into orders, \&c, and descriptions of several new genera and species. Transactions of the Linnean Society, Lonsdon 11: 306-400.

Liljeborg W. 1852. Norges Crustacéer. Crustacea, a clariss. M. W. v. Dueben in Norvegica ad Christiansund et Bergen 1843-44 collecta. Öfversikt Kungliga Vetenskapers Akademi Förhandlingar 8(1851): 19-25.

Liljeborg W. 1855. Öfversigt af de inom Skandinavien hittils funna arterna af slägtet Gammarus Fabr. Kungliga Vetenskaps Akademi Handlingar (1853): 443-460.

Lincoln RJ. 1979. British Marine Amphipoda: Gammarida. British Museum of Natural History, London.

Linnaeus C. 1758.Systema Naturae. Laurentii Salvii, Holmiae (Stockholm). Editio Decima, Tomus 1.

Maren MJ van. 1975. The biology of Marinogammarus marinus (Leach) and Eulimnogammarus obtusatus (Dahl) with some notes on the other intertidal gammarid species (Crustacea, Amphipoda). Bijdragen tot de Dierkunde 45: 205-224.

Meurs H-G, Zauke GP. 1988. Regionale und zeitliche Aspekte der Besiedlung des Elbe-, Weser- und Ems-Ästuars mit euryhalinen Gammariden (Crustacea: Amphipoda). Archiv für Hydrobiologie 113: 213-230.

Movaghar C-A. 1964. Verbreitung und Ökologie der Amphipoden im Elbe-Aestuar. Archiv für Hydrobiologie, Suppl. 29: 97-179.

Nijssen H, Stock JH. 1966. The amphipod, Gammarus tigrinus Sexton, 1939, introduced in the Netherlands. Beaufortia 13: 197-206.

Oldevig H. 1959. Arctic, subarctic and Scandinavian amphipods in the collections of the Swedish Natural History Museum in Stockholm. Göteborgs Kungliga Vetenskaps- och Vitterhets Samhällets Handlingar 7. Följd, Ser B, 8(2): 1-132, pls. 1-4.

Palerud R, Gulliksen B, Brattegard T, Sneli JA, Vader W. 2004. The marine macro-organisms in Svalbard waters. Norwegian Polar Institute, Skrifter 2015-56.

Pinkster S. 1970. Redescription of Gammarus pulex (Linnaeus, 1758) based on neotype material (Amphipoda). Crustaceana 18: 177-186.

Pinkster S, Dennert AL, Stock B, Stock JH. 1970. The problem of European freshwater populations of Gammarus duebeni
Liljeborg, 1852. Bijdragen tot de Dierkunde 40: 116-147.

Pinkster S, Stock JH. 1970. Western European species of the presumed Baikal-genus Eulimnogammarus (Crustacea Amphipoda), with description of a new species from Spain. Bulletin Zoologisch Museum Universiteit Amsterdam 1: $205-$ 219.

Pirlot J-M. 1939. Résultats scientifiques des croisières du navireécole 'Mercator' II. III Amphipoda. Mémoires du Muséum Royal d'Histoire Naturelle Belgique 15: 47-80.

Rathke H. 1843. Beiträge zur Fauna Norwegens. Verhandlungen der Kaiserlichen Leopoldinisch-Carolinischen Akademie der Naturforscher 20(1): 1-264. doi: 10.5962/bhl.title.120119

Reid DM. 1938. Gammarus marinus Leach, var. nov. stoerensis (Crustacea, Amphipoda). Annals and Magazine of Natural History (11)1: 287-289.

Reid DM. 1939. Gammarus sarsi sp.n. (Crustacea, Amphipoda). Annals and Magazine of Natural History (11)10: 281-285.

Reid DM. 1944. Gammaridae (Amphipoda); with a key to the families of British Gammaridea. Linnean Society of London, Synopses British Fauna 3: 1-33.

Reid DM. 1945. Gammarus ochlos (nom. nov.), Crustacea: Amphipoda. Annals and Magazine of Natural History (11)12: 637-638.

Ruoff K. 1968. Experimentelle Untersuchungen über den in die Weser eingebürgerten amerikanischen Bachflohkrebs Gammarus tigrinus Sexton. Archiv für Fischereiwissenschaft19: 134-158.

Sars GO. 1863. Beretning om en i Sommeren 1862 foretagen zoologisk Reise i Christiania og Throndhjems Stifter. Nytt Magasin for Naturvidenskaben 12: 193-252.

Sars GO. 1867. Histoire naturelle des Crustacés d'eau douce de Norvège. I. les Malacostracés. Chr. Johnson, Christiania.

Sars GO. 1890-95. Amphipoda. An Account of the Crustacea of Norway 1. Christiania and Copenhagen. Alb. Cammermeyers Forlag.

Schellenberg A. 1942. Krebstiere oder Crustacea. IV: Flohkrebse oder Amphipoda. Tierwelt Deutschlands 40: 1-252.

Segerstråle SG. 1947. New observations on the distribution and morphology of the amphipod, Gammarus zaddachi Sexton, with notes on related species. Journal of the Marine Biological Association UK 27: 219-244.

Segerstråle SG. 1948. On collections of Gammarus (Amphipoda) from Arctic waters (Coast Potsamo-Kanin, coast of Siberia). Commentationes Biologicae 10(6): 1-13.

Segerstråle SG. 1954. The freshwater amphipods Gammarus pulex (L.) and Gammarus lacustris G.O. Sars, in Denmark and Fennoscandia - a contribution to the late- and postglacial immigration history of the aquatic fauna of northern Europe. Commentationes Biologicae 15(1): 1-91.

Sexton EW 1912. Some brackish-water Amphipoda from the mouths of the Weser and the Elbe, and from the Baltic. Proceedings of the Zoological Society of London (1912): 656665, pls 73-74.

Sexton EW. 1923. On the rearing and breeding of Gammarus in laboratory conditions. Journal of the Marine Biological Association UK 15: 33-55.

Sexton EW. 1939. On a new species of Gammarus (G. tigrinus) from Droitwich District. Journal of the Marine Biological Association UK 23: 543-551, pls 4-6. 
Sexton EW. 1942. The relation of Gammarus zaddachi Sexton to some other species of Gammarus occurring in fresh, estuarine and marine waters. Journal of the Marine Biological Association UK 25: 575-606, pls 1-3.

Sexton EW, Clark R. 1936. A summary of the work on the amphipod Gammarus chevreuxi Sexton carried out at the Plymouth Laboratory 1912-1936. Journal of the Marine Biological Association UK 21: 357-414.

Sexton EW, Spooner GM. 1940. An account of Marinogammarus (Schellenberg) gen. nov. (Amphipoda), with a description of a new species, $M$. pirloti. Journal of the Marine Biological Association UK 24: 633-682, pl. 4.

Shoemaker CS. 1938. Two new species of amphipod crustaceans from the east coast of the United States. Journal of the Washington Academy of Sciences 28:326-332.

Skadsheim A. 1982. The ecology of intertidal amphipods in the Oslofjord. The life cycles of Chaetogammarus marinus and $C$. stoerensis. P.S.Z.N.I: Marine Ecology 3: 213-234.

Skadsheim A. 1983. The ecology of intertidal amphipods in the Oslofjord. Distribution and responses to physical factors. Crustaceana 44: 225-244.

Skadsheim A. 1984. Life cycles of Gammarus oceanicus and G. salinus (Amphipoda) in the Oslofjord, Norway. Holarctic Ecology 7: 262-270.

Sket B. 1971. Zur Systematik und Phylogenie der Gammarini (Amphipoda). Bulletin Scientifique. 16(1-2): 6.

Spikkeland I, Kasbo R, Kjellberg G, Nilssen JP, Opsahl R, Vaaler JP. 2012. Istidsinnvandrere ("istidsrelikter") i ferskvann--nye observasjoner og oppdatering av utbredelsen i Norge. Fauna, Oslo 65: 82-96.

Spikkeland I, Olsen KM, Kinsten B, Kjellberg G. 2016. Ferskvannsamfipoden Crangonyx pseudogracilis påvist $\mathrm{i}$ Norge. Fauna, Oslo 69: 24-34.

Spooner GM. 1947. The distribution of Gammarus species in estuaries I. Journal of the Marine Biological Association UK 27: $1-52$.

Spooner GM. 1951. On Gammarus oceanicus Segerstråle. Journal of the Marine Biological Association UK 30: 129-141.

Spooner GM. 1957. Amphipoda. Pp 207-254 in Marine Biological Association. Plymouth Marine Fauna, 3d edition. Plymouth.

Steele DH, Steele VJ. 1969. The biology of Gammarus (Crustacea, Amphipoda) in the northwestern Atlantic. I. Gammarus duebeni Lilj. Canadian Journal of Zoology 47: 235-244.

Steele DH, Steele. VJ 1970.The biology of Gammarus (Crustacea, Amphipoda) in the northwestern Atlantic. III. Gammarus obtusatus Dahl. Canadian Journal of Zoology 48: 989-995.

Steele DH, Steele VJ. 1972. The biology of Gammarus (Crustacea, Amphipoda) in the northwestern Atlantic.VI. Gammarus tigrinus Sexton. Canadian Journal of Zoology 50: 1063-1068.

Steele DH, Steele VJ. 1975. The biology of Gammarus (Crustacea, Amphipoda) in the northwestern Atlantic. X. Gammarus finmarchicus Dahl. Canadian Journal of Zoology 53: 1110-1115.

Steele VJ, Steele DH. 1970, The biology of Gammarus (Crustacea, Amphipoda) in the northwestern Atlantic.II Gammarus setosus Dementieva. Canadian Journal of Zoology 48: 659-671.

Steele VJ, Steele DH. 1972. The biology of Gammarus (Crustacea, Amphipoda) in the northwestern Atlantic. V, Gammarus oceanicus Segerstråle. Canadian Journal of Zoology 50: 801813.
Steen E. 1951. Ecological observations on some Gammarus and Marinogammarus species on the Scandinavian west coast. Oikos 3: 232-242.

Stephensen K. 1928. Storkrebs II. Ringkrebs I. Tanglopper. Danmarks Fauna 32: 1-399.

Stephensen K. 1929. Amphipoda. Tierwelt Nord- und Ostsee 14 (f): $1-188$

Stephensen K. 1935-42. The Amphipoda of northern Norway and Spitsbergen with adjacent waters. Tromsø Museums Skrifter 3: 1- 526.

Stock JH. 1966. A key to the species of the locusta-group of the amphipod genus Gammarus, with notes on their nomenclature. Bulletin Zoologisch Museum Universiteit Amsterdam 1: 1-5.

Stock JH. 1967. A revision of the European species of the Gammarus locusta-group (Crustacea; Amphipoda). Zoologische Verhandelingen, Leiden 90: 3-56.

Stock JH. 1968. A revision of the European species of the Echinogammarus pungens-group (Crustacea, Amphipoda). Beaufortia 16: 13-78.

Stock JH. 1969a. Rivulogammarus, an amphipod name that must be rejected. Crustaceana 17: 106-107.

Stock JH. 1969b. Members of Baikal amphipod genera in European waters, with description of a new species, Eulimnogammarus macrocarpus, from Spain. Proceedings Koninklijke Academie van Wetenschappen, Ser. C 72: 66-75.

Stock JH, Kant P. 1966. What is Gammarus campylops of Sars, 1894. Bulletin Zoologisch Museum Universiteit Amsterdam 1: 7-17.

Stock JH, Nyssen H, Kant P. 1966. La répartition ecologique des amphipodes de la famille des Gammaridae dans la Slack et son estuaire. Bulletin Zoologisch Museum Universiteit Amsterdam 1: 19-29.

Stock JH, Pinkster S. 1970. Irish and French fresh water populations of Gammarus duebeni subspecifically different from brackish water populations. Nature, London 228: 874-875.

Tulkki P. 1963. Marinogammarus pirloti Sexton and Spooner (Amphipoda) from the Hardangerfjord, western Norway. Sarsia 10: 23-26.

Tzvetkova NL. 1975. Coastal waters Gammarids of northern and far-east seas of SSSR and adjacent waters. Nauka, Leningrad. 257pp. (in Russian)

Vader W. 1965. Het biotoop van de Nederlandse Marinogammarus soorten. De Levende Natuur 68: 205-212.

Vader W. 1969. Notes on a collection of Amphipoda from the Trondheimsfjord area. Det Kongelige Norske Videnskabers Selskaps Skrifter 1969 (3): 1-20.

Vader W. 1971. Additions to the amphipod fauna of northern Norway. Astarte 4: 47-51.

Vader W. 1972. Nye funn av Gammarus zaddachi i Vest- og NordNorge. Fauna 25:35-38

Vader W. 1977a. Occurrence and biotope of Gammarus zaddachi Sexton, 1912 in western and northern Norway. Crustaceana, Suppl. 4: 192-200.

Vader W. 1977b. Gammarus zaddachi i Finnmark. Fauna, Oslo 30: $127-133$.

Vader W, Brattegard T, Buhl-Mortensen L, Miskov Larsen K. 1997. Distribution of marine, benthic macoorganisms in Norway. A tabulated catalogue. Preliminary edition. Amphipoda Gammaridea. Research Reports for DN. Trondheim 1997-1: 
191-212.

Vader W, Christophersen C, Skadsheim A. 1984. Gammarus inaequicauda Stock, 1966 in Norway. Fauna Norvegica Ser. A 5: 9-13.

Węsławski JM. 1994. Gammarus (Crustacea, Amphipoda) from Svalbard and Franz Josef Land. Distribution and density. Sarsia 79: 145-150.

Węsławski JM, Draganska-Deja K, Legeżynska J, Walczowski W. 2018. Range extension of a boreal amphipod Gammarus oceanicus in the warming Arctic. Ecology and Evolution. 8(15): 7624-7632. doi: 10.1002/ece3.4281

Økland KA. 1965. Om krepsdyr av slekten Gammarus i ferskvann og brakkvann i Norge. Fauna18: 53-62.

Økland KA. 1969. On the distribution and ecology of Gammarus lacustris G.O.Sars in Norway, with notes on its morphology and biology. Nytt Magasin for Zoologi 17: 111-152.

Økland KA. 1970. Om marfloen, Gammarus duebeni, i ferskvann og et nytt funn fra Sør-Trøndelag. Fauna 23: 190-195.

Økland KA. 2011. Artsbestemmelse av krepsdyr (Crustacea, Amphipoda) i fersk og brakt vann i Norge: slekten Gammarus og istidskreps. Fauna 64, 2-10.

Økland KA, Økland J, Økland F. 2011. Overraskende funn av brakkvannsmarfloen Gammarus zaddachi i dypet av en innsjø. Fauna 64: 12-17.

Editorial responsibility: Torkild Bakken.

This article is open-access and distributed under the terms of the Creative Commons Attribution 4.0 International license. This permits all non-commercial use, distribution, and reproduction in any medium, provided the original work is properly cited.

(http://creativecommons.org/licenses/by/4.0/). 